\title{
The Variation of Selected Physiological Parameters in Elm Leaves (Ulmus glabra Huds.) Infested by Gall Inducing Aphids
}

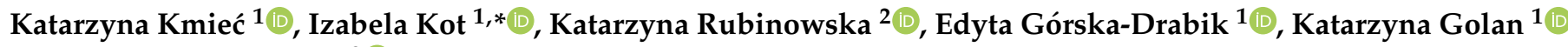 \\ and Hubert Sytykiewicz ${ }^{3}$ (D)
}

1 Department of Plant Protection, University of Life Sciences in Lublin, Leszczyńskiego 7, 20-069 Lublin, Poland; katarzyna.kmiec@up.lublin.pl (K.K.); edyta.drabik@up.lublin.pl (E.G.-D.); katarzyna.golan@up.lublin.pl (K.G.)

2 Department of Botany and Plant Physiology, University of Life Sciences in Lublin, Akademicka 15, 20-950 Lublin, Poland; katarzyna.rubinowska@up.lublin.pl

3 Institute of Biological Sciences, Siedlce University of Natural Sciences and Humanities, Prusa 12, 08-110 Siedlce, Poland; hubert.sytykiewicz@uph.edu.pl

* Correspondence: izabela.kot@up.lublin.pl

\section{check for}

Citation: Kmieć, K.; Kot, I.

Rubinowska, K.; Górska-Drabik, E.; Golan, K.; Sytykiewicz, H. The Variation of Selected Physiological Parameters in Elm Leaves (Ulmus glabra Huds.) Infested by Gall

Inducing Aphids. Plants 2022, 11, 244. https: / /doi.org/10.3390/

plants11030244

Academic Editor: Pasquale Trematerra

Received: 20 December 2021

Accepted: 15 January 2022

Published: 18 January 2022

Publisher's Note: MDPI stays neutral with regard to jurisdictional claims in published maps and institutional affiliations.

Copyright: (C) 2022 by the authors. Licensee MDPI, Basel, Switzerland. This article is an open access article distributed under the terms and conditions of the Creative Commons Attribution (CC BY) license (https:// creativecommons.org/licenses/by/ $4.0 /)$

\begin{abstract}
Three aphid species, Eriosoma ulmi (L.), Colopha compressa (Koch) and Tetraneura ulmi (L.) induce distinct gall morphotypes on Ulmus glabra Huds.; opened and closed galls. Because the trophic relationship of aphids and their galls shows that throughout the gall formation aphids can elicit multiple physiological regulations, we evaluated the changes of hydrogen peroxide content $\left(\mathrm{H}_{2} \mathrm{O}_{2}\right)$, cytoplasmic membrane condition, expressed as electrolyte leakage $\left(\mathrm{E}_{\mathrm{L}}\right)$ and concentration of thiobarbituric acid reactive substances (TBARS), as well as, the activity of catalase (CAT), guaiacol peroxidase (GPX) and ascorbate peroxidase (APX) in gall tissues, as well as, in damaged and undamaged parts of galled leaves. All aphid species increased $\mathrm{E}_{\mathrm{L}}$ from gall tissues and significantly upregulated APX activity in galls and galled leaves. Alterations in $\mathrm{H}_{2} \mathrm{O}_{2}$ and TBARS concentrations, as well as GPX and CAT activities, were aphid- and tissue-dependent. The development of pseudoand closed galls on elm leaves did not have a clear effect on the direction and intensity of the host plant's physiological response. The different modes of changes in $\mathrm{H}_{2} \mathrm{O}_{2}$, TBARS, CAT and GPX were found in true galls of C. compressa and T. ulmi. Generally, physiological alterations in new plant tissues were quite different compared to other tissues and could be considered beneficial to galling aphids.
\end{abstract}

Keywords: antioxidant enzymes; biotic stress; Colopha compressa; Eriosoma ulmi; Tetraneura ulmi

\section{Introduction}

Host plants and insects interact at various levels, and gall formation is seen as a unique and extreme form of relationship. Insects as 'gall-inducers' change active differentiation and growth of plant tissues, manifested as remodeling of host anatomy and metabolism [1-3]. The development of plant galls depends on insect activity because each species uses a specific galling site and induces galls of different shapes and sizes [4-6]. Colopha compressa (Koch), Eriosoma ulmi (L.) and Tetraneura ulmi (L.) aphids have complex life cycles, with alternating sexual and parthenogenetic generations. In the spring, they induce galls on the leaf surfaces of various elm (Ulmus spp.) species as the primary host. Gall is induced only by first instar larva of neonate fundatrix hatching from an overwintered egg. When the gall is fully grown, the gall founder gives birth to offspring that develop into winged emigrant aphids that leave the gall and fly to the secondary host. Eggs are deposited on the trunk of the primary host by apterous sexual females, which are produced by alate migrants returning from the secondary host [7-9]. T. ulmi induces bean-shaped, stalked galls with a green, smooth surface. They are mostly formed on the apical part of the leaf blade. A single gall is initiated by a single fundatrix; however, many aphids can start the galling process on the same leaf. During gall formation, specific leaf distortions are observed $[7,10]$. 
Pocket galls of $C$. compressa are formed by a single fundatrix near the midrib. A single gall is laterally compressed, yellowish with a red tint, and looks like a cockscomb. It is situated mostly on the basal part of the leaf lamina and visible discoloration of leaf blades below the gall is observed [11,12]. Open, leaf-roll pseudogalls are induced usually by one, sporadically even several young E. ulmi fundatrices. Due to aphid feeding, the lateral edge of the leaf blade rolls up downwards, twisting, and blistering, thereby gradually forming a pseudogall $[8,9]$.

The induction and development of galls is a biotic factor affecting plant condition and exposing host tissues to oxidative stress [1,13-17]. It is well known that host plants can initiate signal transduction in response to insect feeding and activate related physiological and biochemical reactions. Reactive oxygen species (ROS) are molecules of defense signaling pathways with known involvement in the activation of plant response to aphid attack $[18,19]$. Hydrogen peroxide $\left(\mathrm{H}_{2} \mathrm{O}_{2}\right)$, as one of ROS, is relatively stable, mildly reactive and electrically neutral. It is able to pass through cell membranes and reach cell locations distant from the site of its formation. This ROS is important for signaling in plant growth and developmental processes as well as in reaction to biotic and abiotic stresses along with programmed cell death (PCD) [20]. The consequence of ROS overproduction is damage to proteins, DNA and lipids that may result in loss of function and formation of cytotoxic, low molecular weight degradation products [18,21,22]. ROS interfere with signaling pathways, thereby leading to the scavenging and detoxification of free radicals and other intermediates through antioxidant systems. Plants can control generated ROS by a set of antioxidants, for example, antioxidant enzymes, including catalase (CAT), which removes hydrogen peroxide by converting it into water and oxygen, and several peroxidases, which can also reduce $\mathrm{H}_{2} \mathrm{O}_{2}[20,23]$. Guaiacol peroxidase (GPX) is a member of a large multigenic heme-containing enzyme family that controls ROS generation when plants are challenged with various stressors [23]. It also oxidizes a variety of phenolic compounds and participates in a broad range of physiological processes, like auxin catabolism, lignification and degradation of the cell wall [24]. $\mathrm{H}_{2} \mathrm{O}_{2}$ accumulation in plant cells is also controlled by ascorbate peroxidase (APX,), a key enzyme of the ascorbate-glutathione (ASA-GSH) cycle. APX is abundantly present in plant cells, and its isoforms acquire a significantly higher affinity for $\mathrm{H}_{2} \mathrm{O}_{2}$ than CAT [20], but the knowledge regarding the APX activity in plants challenged by insects is limited [25].

Aphids secrete during feeding a proteinaceous salivary sheath that lines the stylet path, as well as watery saliva containing numerous enzymes, such as oxidases, pectinases, or cellulases [26]. However, the ability of gall-inducing aphids to alter indirect plant defenses and the distribution of defensive compounds are poorly understood [4,11,12,15,17,27-33]. Therefore, to clarify the physiological changes in galls which can notable variability depending on gall-inducing species, host plant, or feeding period, we analyzed the $\mathrm{H}_{2} \mathrm{O}_{2}$ concentration, cytoplasmic membrane condition, and changes in the activity of catalase and peroxidases, such as GPX and APX. We attempted to determine changes in different parts in different parts of Ulmus glabra Huds. leaves galled by E. ulmi, C. compressa and T. ulmi. A similar pattern of host plant physiological reactions caused by C. compressa and T. ulmi feeding was expected, as both aphid species stimulate plant tissue to produce true (closed) galls on the upper side of the leaf blade, as opposed to E. ulmi, which induces pseudogalls.

\section{Material and Methods}

\subsection{Plant Material and Samplings}

The research was carried out on Ulmus glabra Huds. trees which are part of urban green areas of Lublin, Poland $\left(51.24^{\circ} \mathrm{N}, 22.57^{\circ} \mathrm{S}\right)$. The galling activity of $C$. compressa, $E$. ulmi and T. ulmi is not synchronized, because fundatrices hatch from eggs at a different time. Thus, leaves galled by a particular aphid species and corresponding intact leaves were analyzed separately according to developmental differences of galls. Samples were taken when the galls were fully developed with a fundatrix and its offspring (2nd and 3rd stage) feeding inside. One sample consisted of 20 leaves with galls (for each aphid 
species) taken from 3-4 different trees within hand's reach. Phenologically similar intact leaves situated on the shoots without galls were taken as control. Galled and intact leaves were detached from the same trees with scissors and kept in plastic bags. In the laboratory, within $1 \mathrm{~h}$ after collection, galls and pseudogalls were cut off from the leaves using a scalpel, and the aphids were removed by a soft brush. Parts of the leaf blade with visible damage were separated. For C. compressa and T. ulmi plant material was categorized as four combinations of the experiment: (1) control (intact) leaves, (2) undamaged parts of the lamina (without visible discoloration and corrugation) of galled leaves, (3) damaged parts of galled leaves, (4) galls alone. Three combinations were applied for E. ulmi, namely (1) intact leaves, (2) undamaged portions of galled leaves and (3) pseudogalls.

\subsection{Measurement of Hydrogen Peroxide, Lipid Peroxidation and Electrolyte Leakage}

Hydrogen peroxide $\left(\mathrm{H}_{2} \mathrm{O}_{2}\right)$ content was estimated by forming a titanium-hydroperoxide complex [34]. Fresh plant material $(0.5 \mathrm{~g})$ was ground in $3 \mathrm{~mL}$ of phosphate buffer $(50 \mathrm{mM}$, $\mathrm{pH}$ 6.5) at $4{ }^{\circ} \mathrm{C}$, the mixture was centrifuged at $6000 \times \mathrm{g}$ for $25 \mathrm{~min}$. Next, $1.5 \mathrm{~cm}^{3}$ of the supernatant was added to $0.5 \mathrm{~cm}^{3}$ titanium sulfate in $20 \% \mathrm{H}_{2} \mathrm{SO}_{4}(v / v)$ and centrifuged at $6000 \times g$ for $15 \mathrm{~min}$. The absorbance of the supernatant was measured at $410 \mathrm{~nm}$ against a blank reagent with a Cecil CE 9500 spectrophotometer (Cecil Instruments, Cambridge England). The $\mathrm{H}_{2} \mathrm{O}_{2}$ concentration in the sample was calculated using the molar absorbance coefficient $0.28 \mu \mathrm{M}^{-1} \mathrm{~cm}^{-1}$, and are expressed as nanomoles per $1 \mathrm{~g}$ fresh weight.

The membrane lipid peroxidation was assessed by determining thiobarbituric acid reactive substances (TBARS) content according to Heath and Packer [35]. Crushed plant material $(0.2 \mathrm{~g})$ was homogenized in $0.1 \mathrm{M}$ potassium phosphate buffer, $\mathrm{pH} 7.0$, and centrifuged at $12,000 \times g$ for $20 \mathrm{~min}$. Next, $0.5 \mathrm{~cm}^{3}$ of the homogenate was added to $2 \mathrm{~cm}^{3}$ $20 \%$ trichloroacetic acid (TCA) containing $0.5 \%$ thiobarbituric acid (TBA) incubated in a water bath at $95{ }^{\circ} \mathrm{C}$ for $30 \mathrm{~min}$, quickly cooled and centrifuged at $10,000 \times g$ for $10 \mathrm{~min}$. The absorbance was measured at 532 and $600 \mathrm{~nm}$ with a spectrophotometer mentioned above. The TBARS concentration in the samples was calculated using the molar absorbance coefficient $\left(155 \mathrm{nM}^{-1} \mathrm{~cm}^{-1}\right)$. Results are presented as nanomoles per $1 \mathrm{~g}$ fresh weight.

Electrolyte leakage $\left(\mathrm{E}_{\mathrm{L}}\right)$ was measured with an Elmetron CC-317 microcomputer conductometer. Ten leaf/gall rings ( $9 \mathrm{~mm}$ diameter) were cut using a cork borer from each sample. The plant material was placed in test tubes containing $20 \mathrm{~cm}^{3}$ distilled deionized water. The tubes were incubated on the rotary shaker for $24 \mathrm{~h}$ at room temperature, and the initial electrical conductivity (K1) was determined. Then, the samples were autoclaved at $100{ }^{\circ} \mathrm{C}$ for $15 \mathrm{~min}$, and after $24 \mathrm{~h}$ of shaking the final conductivity of the solution was measured (K2). Electrolyte leakage was calculated using the formula: $\mathrm{E}_{\mathrm{L}}(\%)=(\mathrm{K} 1 / \mathrm{K} 2) \times 100[36]$.

\subsection{Assay of Antioxidant Enzymes Activities}

Fresh leaf material $(0.2 \mathrm{~g})$ was homogenized with $10 \mathrm{~cm}^{3}$ of $50 \mathrm{mM}$ phosphate buffer, pH 7.0 containing 0.2 M EDTA (ethylenediaminetetraacetic acid) and 2\% PVP (polyvinylpyrrolidone). The homogenate was centrifuged at $10,000 \times \mathrm{g}$ for $15 \mathrm{~min}$ at $4{ }^{\circ} \mathrm{C}$, and obtained supernatant was used for enzyme analysis. Absorbance readings were performed using a Cecil CE 9500 spectrophotometer.

Catalase (CAT; EC 1.11.1.6) activity was measured by Chance and Meahly [37] method with Wiloch et al. [38] modification. The reaction mixture contained $2 \mathrm{~cm}^{3}$ of $50 \mathrm{mM}$ potassium phosphate buffer $\mathrm{pH} 7.0,0.2 \mathrm{~cm}^{3}$ of $\mathrm{H}_{2} \mathrm{O}_{2}$ and $0.1 \mathrm{~cm}^{3}$ of supernatant. The extinction was measured for $3 \mathrm{~min}$ reading at the initial and final stage at $240 \mathrm{~nm}$. Catalase activity was determined using the absorbance coefficient $0.036 \mathrm{mM}^{-1} \mathrm{~cm}^{-1}$. The results were converted to catalase activity per fresh weight, expressed as $\mathrm{U} \mathrm{mg}^{-1}$ fresh weight. The activity of peroxidase towards guaiacol (GPX; EC 1.11.1.7) was assayed as described by Małolepsza et al. [39]. The reaction mixture contained $0.5 \mathrm{~cm}^{3}$ of $0.05 \mathrm{M}$ acetate buffer $\mathrm{pH} 5.6,0.5 \mathrm{~cm}^{3}$ of $0.02 \mathrm{M}$ guaiacol, $0.5 \mathrm{~cm}^{3}$ of $0.06 \mathrm{M} \mathrm{H}_{2} \mathrm{O}_{2}$ and $0.5 \mathrm{~cm}^{3}$ of supernatant. The absorbance was measured at 1-min intervals for 4 min at $480 \mathrm{~nm}$. GPX activity was 
calculated using the absorbance coefficient $26.6 \mathrm{mM}^{-1} \mathrm{~cm}^{-1}$. GPX activity was expressed as a change of peroxidase activity per fresh weight, expressed as $\mathrm{U} \mathrm{mg}^{-1}$ fresh weight. Ascorbate peroxidase (APX, EC 1.11.1.11) activity was determined according to Nakano and Asada [40]. The reaction mixture contained $1.8 \mathrm{~cm}^{3} 0.1 \mathrm{M}$ phosphate buffer $\mathrm{pH} 6.0$, $0.02 \mathrm{~cm}^{3}$ of $5 \mathrm{mM}$ sodium ascorbate, $0.1 \mathrm{~cm}^{3}$ of $1 \mathrm{mM} \mathrm{H}_{2} \mathrm{O}_{2}$ and $0.1 \mathrm{~cm}^{3}$ of the supernatant. Absorbance was monitored at a wavelength of $290 \mathrm{~nm}$ for $5 \mathrm{~min}$, measured at $1 \mathrm{~min}$ intervals. APX activity was calculated using the absorbance coefficient of $2.8 \mathrm{mM}^{-1} \mathrm{~cm}^{-1}$. Its activity was defined as the change of peroxidase activity per fresh weight, expressed as $\mathrm{U} \mathrm{mg}^{-1}$ fresh weight.

\subsection{Data Analysis}

All physiological analyses were conducted in three biological replications $(n=3)$. Oneway ANOVA was used to distinguish physiological reactions of different host plant tissues to the feeding of particular aphid species. Differences between means were determined using Tukey's simultaneous test (HSD), and the level of significance was set at $\alpha=0.05$. Data are presented as means with standard deviation. The percentage change was calculated in the $\mathrm{E}_{\mathrm{L}}, \mathrm{TBARS}$ and $\mathrm{H}_{2} \mathrm{O}_{2}$ content, and enzymatic activity in galled plant tissues relative to the intact leaves (as 100\%). The obtained data were log-transformed. Differences in the mean percentage change in the content/activity of all analyzed parameters between tissues (undamaged, damaged, and gall) influenced by three aphid species were examined with factorial ANOVA/MANOVA, preceded by the Kolmogorov-Smirnov test. Means were separated by Tukey's HSD test for unequal numbers, with the level of significance set at $\alpha=0.05$. All analyses were performed using Statistica 13.1 (StatSoft, Krakow, Poland) [41].

\section{Results}

Feeding of C. compressa, E. ulmi and T. ulmi affected $\mathrm{H}_{2} \mathrm{O}_{2}$ and TBARS level, electrolyte leakage from the cells, as well as antioxidant enzymes activity in host plant tissues. The percentage change in the level/activity of analyzed parameters was dependent on aphid species, tissue type as well as their interactions (Table 1).

Table 1. Analysis of variance (ANOVA/MANOVA) in percentage changes relative to the intact leaves (as $100 \%$ ) in hydrogen peroxide $\left(\mathrm{H}_{2} \mathrm{O}_{2}\right)$ and thiobarbituric acid reactive substances (TBARS) content, electrolyte leakage $\left(\mathrm{E}_{\mathrm{L}}\right)$, as well as, catalase (CAT), peroxidase towards guaiacol (GPX) and ascorbate peroxidase (APX) activities with aphid species and host tissue as categorical factors.

\begin{tabular}{ccccccc}
\hline & \multicolumn{2}{c}{ Aphid Species } & \multicolumn{2}{c}{ Type of Host Tissue } & \multicolumn{2}{c}{$\begin{array}{c}\text { Aphid Species x Type of } \\
\text { Host Tissue }\end{array}$} \\
\cline { 2 - 7 } Parameter & $d f$ & $\mathbf{1}$ & $d f$ & $\mathbf{1}$ & $d f$ & $\mathbf{3}$ \\
\cline { 2 - 7 } & $\boldsymbol{F}$ & $\boldsymbol{P}$ & $\boldsymbol{F}$ & $\boldsymbol{P}$ & $\boldsymbol{F}$ & $\boldsymbol{P}$ \\
\hline$n$ & 59.11 & $<0.001$ & 179.91 & $<0.001$ & 85.99 & $<0.001$ \\
$\mathrm{H}_{2} \mathrm{O}_{2}$ & 171.52 & $<0.001$ & 92.17 & $<0.001$ & 267.23 & $<0.001$ \\
$\mathrm{E}_{\mathrm{L}}$ & 0.01 & $0.941^{*}$ & 118.17 & $<0.001$ & 10.96 & $<0.001$ \\
$\mathrm{CAT}$ & 0.20 & $0.662^{*}$ & 2.70 & $0.120^{*}$ & 38.56 & $<0.001$ \\
GPX & 7.07 & 0.0171 & 171.37 & $<0.001$ & 55.82 & $<0.001$ \\
APX & 35.88 & $<0.001$ & 206.28 & $<0.001$ & 12.16 & 0.0002 \\
\hline
\end{tabular}

An asterisk indicates no significance. Corresponding figure-Figure 1A-C. 

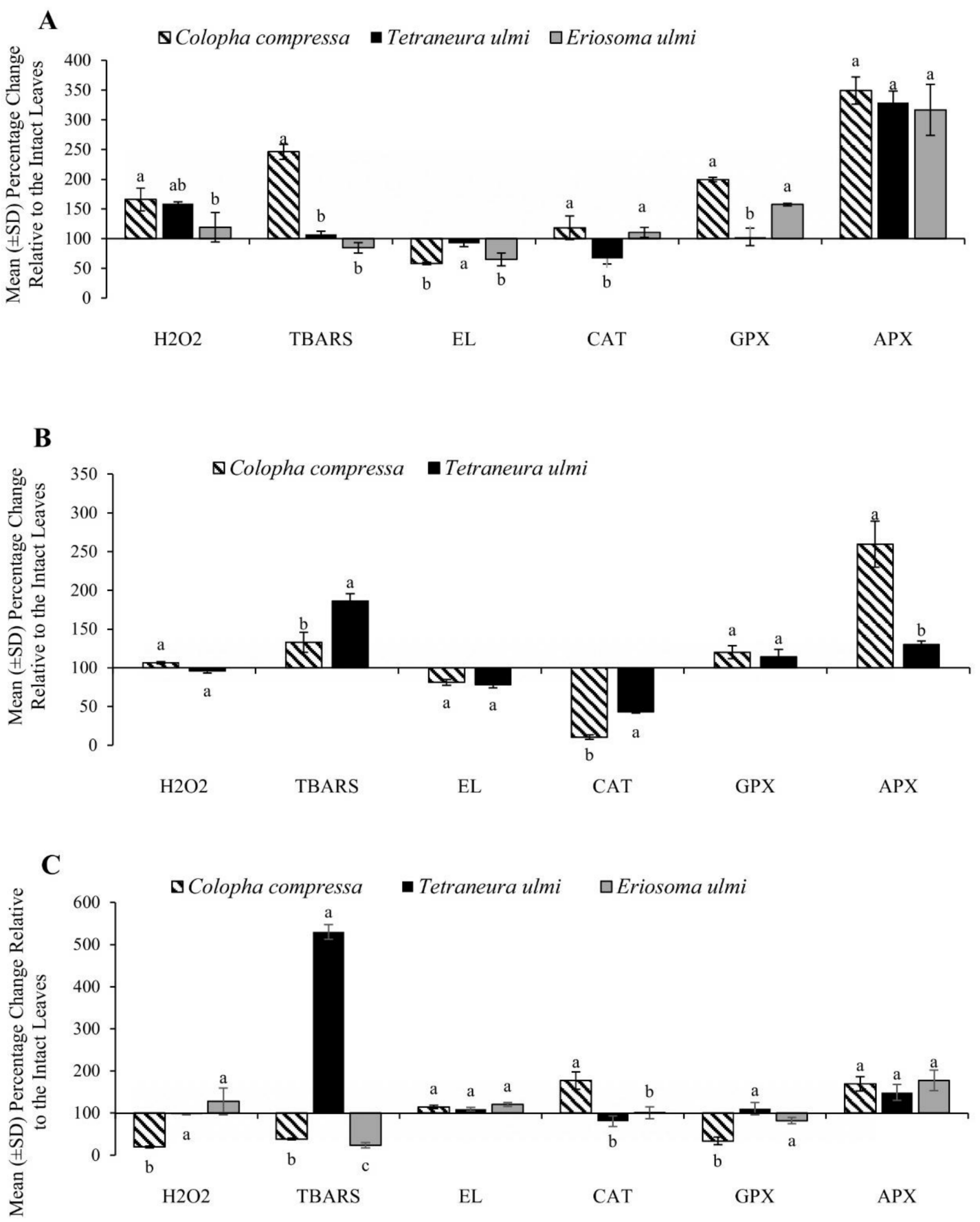

Figure 1. Mean $( \pm \mathrm{SD})$ percentage change (relative to intact leaves as $100 \%)$ in level of hydrogen peroxide $\left(\mathrm{H}_{2} \mathrm{O}_{2}\right)$, electrolyte leakage $\left(\mathrm{E}_{\mathrm{L}}\right)$ and thiobarbituric acid reactive substances (TBARS), as well as, ascorbate peroxidase (APX), peroxidase towards guaiacol (GPX) and catalase (CAT) activities in undamaged parts of galled leaves (A), damaged parts of galled leaves (B), and galls $(\mathbf{C})$ of three aphid species (Eriosoma ulmi (L.), Colopha compressa (Koch) and Tetraneura ulmi (L.)). Bars sharing the same letter according to each parameter do not differ significantly at $p \leq 0.05$ (Tukey's test for unequal numbers).

\subsection{Indicators of Oxidative Stress}

The leaves with galls of C. compressa and T. ulmi showed a similar pattern of $\mathrm{H}_{2} \mathrm{O}_{2}$ concentrations. This molecule reached the highest level in tissues of undamaged parts of galled leaves, whereas its concentration in damaged parts was similar to intact leaves 
(Table 2). In C. compressa gall tissues, hydrogen peroxide content was $80 \%$ lower as compared to control leaves, while in T. ulmi galls, it was similar to the level in intact leaves (Figure 1C). On the other hand, $\mathrm{H}_{2} \mathrm{O}_{2}$ concentration in leaves with E. ulmi pseudogalls was higher in comparison with intact leaves, but differences were not significant (Table 2).

Table 2. The effect of Eriosoma ulmi (L.), Colopha compressa (Koch.), and Tetraneura ulmi (L.) galling on electrolyte leakage $\left(\mathrm{E}_{\mathrm{L}}\right)$, thiobarbituric acid reactive substances (TBARS) and hydrogen peroxide $\left(\mathrm{H}_{2} \mathrm{O}_{2}\right)$ in tissues of Ulmus glabra Huds.

\begin{tabular}{|c|c|c|c|c|}
\hline $\begin{array}{c}\text { Host } \\
\text { Plant/Aphid } \\
\text { Species }\end{array}$ & Type of Tissue & $\begin{array}{l}\mathrm{E}_{\mathrm{L}} \\
\%\end{array}$ & $\begin{array}{c}\text { TBARS } \\
\text { nmol g }^{-1} \text { FW }\end{array}$ & $\begin{array}{c}\mathrm{H}_{2} \mathrm{O}_{2} \\
\mathrm{nmol} \mathrm{g}^{-1} \mathrm{FW}\end{array}$ \\
\hline \multirow{3}{*}{ Eriosoma ulmi } & intact leaves & $45.74 \pm 1.1^{b}$ & $23.66 \pm 1.3^{a}$ & $69.10 \pm 8.2^{\mathrm{a}}$ \\
\hline & galled leaves & $29.74 \pm 0.1^{\mathrm{c}}$ & $20.13 \pm 2.1^{a}$ & $80.53 \pm 5.7^{a}$ \\
\hline & pseudogalls & $55.09 \pm 2.4^{\mathrm{a}}$ & $5.59 \pm 1.1^{\mathrm{b}}$ & $85.26 \pm 3.7^{a}$ \\
\hline \multirow{4}{*}{$\begin{array}{l}\text { Colopha } \\
\text { compressa }\end{array}$} & intact leaves & $30.22 \pm 0.6^{b}$ & $16.19 \pm 0.9^{c}$ & $49.62 \pm 1.0^{b}$ \\
\hline & galled leaves UP & $25.70 \pm 0.7^{c}$ & $39.79 \pm 1.7^{\mathrm{a}}$ & $82.24 \pm 8.3^{a}$ \\
\hline & galled leaves DP & $24.50 \pm 0.5^{\mathrm{c}}$ & $21.26 \pm 0.9^{b}$ & $52.78 \pm 0.8^{b}$ \\
\hline & galls & $34.60 \pm 0.6^{\mathrm{a}}$ & $6.19 \pm 0.3^{d}$ & $9.67 \pm 1.1^{c}$ \\
\hline \multirow{4}{*}{ Tetraneura ulmi } & intact leaves & $30.55 \pm 0.6^{\mathrm{ab}}$ & $22.81 \pm 0.9^{c}$ & $38.81 \pm 0.1^{b}$ \\
\hline & galled leaves UP & $28.16 \pm 1.3^{b}$ & $24.39 \pm 0.3^{c}$ & $61.72 \pm 1.3^{\mathrm{a}}$ \\
\hline & galled leaves DP & $23.82 \pm 0.3^{c}$ & $42.50 \pm 0.2^{b}$ & $37.24 \pm 0.5^{b}$ \\
\hline & galls & $33.34 \pm 0.2^{\mathrm{a}}$ & $122.15 \pm 3.1^{\mathrm{a}}$ & $37.85 \pm 0.6^{b}$ \\
\hline
\end{tabular}

Galled leaves UP—undamaged part of galled leaf lamina, galled leaves DP—damaged part of galled leaf lamina (with visible discoloration and/or corrugation), Mean (+SD) was calculated from three biological replicates for each treatment. Values with different letters, for each plant-aphid system, are significantly different at $p \leq 0.05$ applying Tukey's HSD test.

Lipid peroxidation, as an indicator of oxidative stress, reflected the degree of leaf cell membrane damage due to galling. Undamaged parts of leaves galled by C. compressa were characterized by a $146 \%$ increase of TBARS, while only a $33 \%$ increase was noted in damaged parts of galled leaves in relation to control leaves (Figure 1A,B). The lowest content of TBARS was observed in gall tissues (Table 2). On the other hand, lipid peroxidation in the galls of T. ulmi reached more than a 5-fold increase as compared to the intact leaves (Figure 1C). TBARS content in undamaged parts of leaves galled by this aphid species was similar to control leaves, while it was approximately $90 \%$ higher in the damaged parts (Figure 1A,B). Pseudogalls of E. ulmi showed a clear decrease in TBARS level as compared to intact and galled leaves (Table 2).

The feeding of all aphid species caused an increase in $\mathrm{E}_{\mathrm{L}}$ in gall tissues in comparison with all other leave tissues (Table 2). The galling activity of C. compressa and T. ulmi caused a significant decrease in $\mathrm{E}_{\mathrm{L}}$ levels in damaged parts of galled leaves (Figure 1B). In undamaged parts of all galled leaves, a downward trend of electrolyte leakage was also observed (Figure 1A).

\subsection{Activity of Antioxidant Enzymes}

The presence of T. ulmi resulted in a percentage decrease in CAT activity in galls (Figure 1C) and undamaged (Figure 1A) and damaged (Figure 1B) parts of galled leaves by $19.3 \%, 33.5 \%$ and $56.8 \%$, respectively, compared to $\mathrm{H}_{2} \mathrm{O}_{2}$ concentration, cytoplasmic membrane condition, and changes in the activity of catalase and peroxidases, such as GPX and APX to intact leaves. Its lowest activity was observed in damaged parts of galled leaves. Gall formation by C. compressa induced a significant decrease in catalase activity only in damaged parts of galled leaves (Table 3). However, a slight increase of its activity in undamaged parts of galled leaves (Figure 1A) and in galls (Figure 1C) was also detected. On the other hand, E. ulmi feeding did not alter CAT activity significantly in host plant tissues (Table 3). 
Table 3. The effect of Eriosoma ulmi (L.), Colopha compressa (Koch.), and Tetraneura ulmi (L.) galling on antioxidant enzyme activities (catalase (CAT), peroxidase towards guaiacol (GPX), ascorbate peroxidase (APX)) in tissues of Ulmus glabra Huds.

\begin{tabular}{|c|c|c|c|c|}
\hline Aphid Species & Type of Tissue & $\begin{array}{c}\text { CAT } \\
\mathrm{U} \mathrm{mg}^{-1} \mathrm{FW}\end{array}$ & $\begin{array}{c}\text { GPX } \\
\mathrm{U} \mathrm{mg}^{-1} \mathrm{FW}\end{array}$ & $\begin{array}{c}\text { APX } \\
\mathrm{U} \mathrm{mg}^{-1} \mathrm{FW}\end{array}$ \\
\hline \multirow{3}{*}{ Eriosoma ulmi } & intact leaves & $0.66 \pm 0.0^{a}$ & $9.19 \pm 0.1^{b}$ & $1.37 \pm 0.1^{\mathrm{c}}$ \\
\hline & galled leaves & $0.73 \pm 0.1^{\mathrm{a}}$ & $14.47 \pm 0.3^{\mathrm{a}}$ & $4.31 \pm 0.2^{\mathrm{a}}$ \\
\hline & pseudogalls & $0.67 \pm 0.1^{\mathrm{a}}$ & $7.53 \pm 0.3^{c}$ & $2.41 \pm 0.1^{b}$ \\
\hline \multirow{4}{*}{$\begin{array}{l}\text { Colopha } \\
\text { compressa }\end{array}$} & intact leaves & $0.36 \pm 0.1^{\mathrm{a}}$ & $6.89 \pm 0.3^{b}$ & $0.95 \pm 0.02^{d}$ \\
\hline & galled leaves UP & $0.41 \pm 0.1^{\mathrm{a}}$ & $13.75 \pm 0.8^{a}$ & $3.30 \pm 0.2^{\mathrm{a}}$ \\
\hline & galled leaves DP & $0.04 \pm 0.03^{b}$ & $8.26 \pm 0.2^{b}$ & $2.46 \pm 0.3^{b}$ \\
\hline & galls & $0.49 \pm 0.2^{\mathrm{a}}$ & $2.34 \pm 0.7^{\mathrm{c}}$ & $1.60 \pm 0.1^{\mathrm{c}}$ \\
\hline \multirow{4}{*}{ Tetraneura ulmi } & intact leaves & $1.37 \pm 0.2^{\mathrm{a}}$ & $13.18 \pm 0.1^{\mathrm{a}}$ & $1.86 \pm 0.1^{\mathrm{c}}$ \\
\hline & galled leaves UP & $0.90 \pm 0.1^{b c}$ & $13.45 \pm 0.8^{a}$ & $6.09 \pm 0.1^{\mathrm{a}}$ \\
\hline & galled leaves DP & $0.57 \pm 0.02^{\mathrm{c}}$ & $14.97 \pm 0.1^{\mathrm{a}}$ & $2.41 \pm 0.04^{b}$ \\
\hline & galls & $0.96 \pm 0.04^{b}$ & $14.45 \pm 0.7^{\mathrm{a}}$ & $2.76 \pm 0.3^{b}$ \\
\hline
\end{tabular}

Galled leaves UP_-undamaged part of galled leaf lamina, galled leaves DP_-damaged part of galled leaf lamina (with visible discoloration and/or corrugation), Mean (+SD) was calculated from three biological replicates for each treatment. Values with different letters, for each plant-aphid system, are significantly different at $p \leq 0.05$ applying Tukey's HSD test.

The statistical analysis showed no significant differences in GPX activity in tissues under galling of T. ulmi (Table 3). The presence of other aphid galls altered GPX activity. The highest upregulation of that enzyme activity was recorded in undamaged parts of leaves galled by $C$. compressa and E ulmi. Its activity was almost 2-fold higher during $C$. compressa feeding as compared to the control rate (Figure 1A). In contrast, more than $60 \%$ lower GPX activity was detected in gall tissues of $C$. compressa compared to intact leaves (Figure 1C).

A significantly higher APX activity under the galling of all aphid species was observed. Aphid feeding in galls strongly increased APX activity in galled leaves and gall tissues (Table 3). The highest increase, almost 250\% compared to intact leaves, was recorded in undamaged parts of galled leaves (Figure 1A). APX activity in galls was approximately $50-70 \%$ higher, depending on aphid species (Figure 1C). Significantly higher growth in that enzyme activity was observed in damaged parts of leaves galled by C. compressa than in damaged parts of leaves galled by T. ulmi (Figure 1B).

\section{Discussion}

The evolution of plants and insects has resulted in the development of strategies to avoid each other's defenses [23]. However, many phytophagous species possess the ability to interfere with the tissues of their host plants to produce galls, which are often highly specialized structures $[1,3]$. Recent studies indicated that host plant physiological response to galling aphids is not unequivocal and depends on the insect species.

Physiological and molecular reactions in plants against insect attacks are triggered by reactive oxygen species. Enhancement of ROS production was observed in numerous plant-aphid interactions $[18,19,42,43]$. The feeding activity of galling aphids can promote distinct structural and physiological changes, triggered by ROS alterations in host plant cells $[12,15,44]$. This study showed a marked increase of $\mathrm{H}_{2} \mathrm{O}_{2}$ under the galling of all analyzed aphid species, but only in undamaged parts of galled leaves. Surprisingly, a very low level of this molecule was measured in galls of C. compressa. Kot and Rubinowska [16] provided similar observations concerning different Cynipid species. On the other hand, the infestation of cottonwood by Pempighus spyrothecae Pass. [17], as well as Neotropical plants by galling Psyllidae and Cecidomyiidae [14,45] resulted in high $\mathrm{H}_{2} \mathrm{O}_{2}$ concentrations in the galls. The role of ROS in gall induction, development and functioning does not seem unequivocal. According to Morkunas and co-authors [18], ROS, as common intracellular 
and intercellular messengers with a broad spectrum of regulatory functions, are involved in many physiological processes. Hydrogen peroxide affects the activity of signaling compounds, such as MAP kinases, NADPH oxidase dependent on monomeric G protein, lipid-derived signals, $\mathrm{Ca}^{2+}$ channels, plant hormones, such as salicylic acid, jasmonic acid, abscisic acid, as well as ethylene and transcription factors, and thus they may also trigger gall morphogenesis [3,23]. However, a high concentration of $\mathrm{H}_{2} \mathrm{O}_{2}$ can be toxic to plants due to oxidative damage and may eventually lead to apoptotic cell death. On the other hand, ROS can cause oxidative damage to the insect midgut and reduce nutrient absorption [46].

The hydroxyl radicals may induce lipid peroxidation, which degrades cell structural components. In the current study, the highest amount of TBARS in galls and damaged parts of leaves galled by T. ulmi was observed as opposed to galling activity of C. compressa and E. ulmi, where the lowest amount of TBARS in galls was noted. However, higher TBARS levels were measured in different parts of leaves with true galls when compared to intact leaves. Previous reports indicated that the increase in lipid peroxidation was directly induced in Eucalyptus plants by a gall-forming psyllid [47] and in oak leaves by gallinducing Cynipidae [16]. The products of lipid peroxidation can induce gene expression and are involved in plant signaling [48]. Some of them are highly reactive and participate in several physiological pathways, e.g., cell death, defense induction, signaling protein modification, or as secondary toxic cell messengers [49]. Both true and pseudo-galls wither after adult winged females emerge out of them [10]. It is possible that the cell death process was already triggered in T. ulmi galls similar to the Cecidomyiidae and Aspidosperma system, where signs of degradation and PCD in mature galls were found [13]. In turn, a low concentration of TBARS, accompanied by a decrease in $\mathrm{H}_{2} \mathrm{O}_{2}$ levels, suggested that the antioxidant defense system was activated in different parts of galled leaves and in the galls of C. compressa and E. ulmi, and was effective in free radical detoxification. Disorders in the integrity and stability of plasma membranes, measured by $\mathrm{E}_{\mathrm{L}}$, are widely used as a test for stress-induced plant tissue damage. Electrolyte leakage triggered by all major stressors, including salinity, pathogen attack, heavy metals and wounding is usually accompanied by ROS accumulation and often results in PCD [50]. In our study, the highest level of $\mathrm{E}_{\mathrm{L}}$ in gall tissues, $\mathrm{H}_{2} \mathrm{O}_{2}$ concentration, cytoplasmic membrane condition, and changes in the activity of catalase and peroxidases, such as GPX and APX were observed, which was similar to results in Populus nigra L.-P. spyrothecae system [17]. Aphids, as phloem feeders, penetrate plant cells and inject saliva, which plays a crucial role in preventing plant wound responses, but may also elicit plant reaction, resulting in damage during a later stage of infestation [18]. According to Demidchik and co-authors [50], electrolyte leakage from plant cells is mainly associated with increased $\mathrm{K}^{+}$efflux through potassium channels. Potassium depletion in plants may enhance the activity of enzymes secondarily inducing PCD [43].

CAT, GPX and APX are enzymes representing the main enzymatic ROS scavenging mechanism in plants, and they are capable of scavenging $\mathrm{H}_{2} \mathrm{O}_{2}$ by various mechanisms, and APX is one of the central enzymes in this system [21]. The current research showed a significant increase in APX activity in all host tissues due to galling. Its highest activity was observed in undamaged parts of galled leaves in comparison to control. Various molecular forms of APX within the cells and organelles play important roles in developmental processes, including redox signaling [51]. Enhanced APX activity was also observed in winter triticale after Sitobion avenae (Fab.) and Rhopalosiphum padi L. aphid infestation [52] and soybean seedlings due to Aphis craccivora Koch feeding [25]. Ascorbate peroxidase activity generally increases under biotic and abiotic stresses along with other enzyme activities, such as CAT, SOD, and GSH reductase [53]. However, a significant increase in GPX activity was found in the present study only in undamaged parts of leaves galled by C. compressa and E. ulmi. In turn, the opposite reaction was observed in the galls of these aphid species. Gailite and co-authors [11] obtained similar results. The present study found no significant plant reaction caused by T. ulmi galling activity. Different responses of galls and galled leaves were also observed by Kot and Rubinowska [16] in the Cynipidae-oak 
system. Increased GPX activity is able to control the balance between $\mathrm{H}_{2} \mathrm{O}_{2}$ generation as a defense response and a decrease in hydrogen peroxide level to reduce oxidative damage in plant cells. Furthermore, reactive quinones and other oxidative radicals are produced by GPX in association with phenols, which act as feeding deterrents and generate toxins that reduce the digestibility of plant tissue $[15,23,54]$. It is possible that galling aphids manipulate the plant antioxidant system to avoid detrimental effects. Various CAT isoforms are involved in eliminating $\mathrm{H}_{2} \mathrm{O}_{2}$ generated during photorespiration, $\beta$-oxidation of fatty acids, and purine catabolism [55]. Catalase scavenges toxic and unstable ROS and directly converts them to oxygen and water, and in contrast to APX, it is more involved in $\mathrm{H}_{2} \mathrm{O}_{2}$ detoxification rather than regulation [51]. Our research showed a significant decrease in CAT activity in elm tissues due to T. ulmi feeding. A similar reaction was also found in damaged parts of leaves galled by $C$. compressa. On the other hand, slightly higher CAT activity was observed in the pseudogalls of E. ulmi, and undamaged parts of galled leaves, as well as in galls of $C$. compressa. The previous study documented a significant effect of C. compressa, E. ulmi and T. ulmi on photosynthesis photochemistry of different elm species. The strongest suppression of photosynthesis and pigment content due to $T$. ulmi feeding was found by Kmieć et al. [12]. A possible explanation of that phenomenon was the downregulation of CAT since an increase in its activity in leaves could protect chloroplasts, which presented sustained electron flows and were the main producers of ROS under stress conditions [56]. Mai and co-authors [42] have revealed that different CAT activities in plant responses to aphids suggest that plants have various mechanisms of aphid resistance. In turn, Shim et al. [57] indicated that CAT activity inhibition is a phenomenon that occurs in many plant species exposed to oxidative stress, and is related to salicylic acid accumulation. According to Apel and Hirt [58], when the balance of scavenging enzymes changes, compensatory mechanisms like APX and GPX upregulation and CAT downregulation, are induced in plants.

In conclusion, galling aphid feeding evoked various reactions of host plant tissues. Gall responses were usually quite different from those of leaves, although gall tissues had originated from leaf tissues as neoplastic formations. Physiological alterations of galls suggested manipulation that could be considered beneficial to aphids. Contrary to the hypothesis, different responses of $\mathrm{H}_{2} \mathrm{O}_{2}$, TBARS, CAT and GPX were found in true galls of $C$. compressa and T. ulmi. More detailed research is needed to clarify this phenomenon because gall induction and development is a remarkably dynamic process $[1,15]$.

Author Contributions: Conceptualization, Investigation, Methodology, Writing-Original Draft Preparation, Review and Editing, K.K.; Investigation, Writing-Original Draft Preparation, Review and Editing, I.K.; Software, Writing-Original Draft Preparation, K.G.; Writing-Original Draft Preparation, Review and Editing, H.S. and E.G.-D.; Methodology and Physiological Analyses, K.R. All authors have read and agreed tot he published version of the manuscript.

Funding: This research was supported by the Polish Ministry of Science and Higher Education under statutory funds of University of Life Sciences in Lublin (Project no. OKK/s/44/2020).

Institutional Review Board Statement: Not applicable.

Informed Consent Statement: Not applicable.

Data Availability Statement: Not applicable.

Conflicts of Interest: The authors have no conflicts of interest to declare.

\section{References}

1. Raman, A. Morphogenesis of insect-induced plant galls: Facts and questions. Flora 2011, 206, 517-533. [CrossRef]

2. Isaias, R.M.S.; Oliveira, D.C.; Carneiro, R.G.S.; Kraus, J.E. Developmental anatomy of galls in the Neotropics: Arthropods stimuli versus host plant constraints. In Neotropical Insect Galls; Fernandes, G.W., Santos, J.C., Eds.; Springer: Dordrecht, The Netherlands, 2014; Volume 15, pp. 15-34. 
3. Oliveira, D.C.; Isaias, R.M.S.; Fernandes, G.W.; Ferreira, B.G.; Carneiro, R.G.S.; Fuzaro, L. Manipulation of host plant cells and tissues by gall-inducing insects and adaptive strategies used by different feeding guilds. J. Insect Physiol. 2016, 84, 103-113. [CrossRef]

4. El-Akkad, S.S. Biochemical changes induced in Populus nigra leaves by galling aphid Pemphigous populi. Int. J. Agric. Biol. 2004, 6 , 650-664.

5. Wool, D. Galling aphids: Specialization, biological complexity, and variation. Annu. Rev. Entomol. 2004, 49, 175-192. [CrossRef]

6. Suzuki, D.K.; Fukushi, Y.; Akimoto, S. Do aphid galls provide good nutrients for the aphids?: Comparisons of amino acid concentrations in galls among Tetraneura species (Aphididae: Eriosomatinae). Arthropod-Plant Interact. 2009, 3, 241-247. [CrossRef]

7. Urban, J. Bionomics and harmfulness of Tetraneura ulmi (L.) (Aphidinea, Pemphigidae) in elms. J. Forest Sci. 2003, 49, 159-181. [CrossRef]

8. Urban, J. Biology and harmfulness of Eriosoma (=Schizoneura) ulmi (L.) (Aphidinea, Pemphigidae) in elm. J. Forest Sci. 2003, 49, 359-379. [CrossRef]

9. Blackman, R.L.; Eastop, V.F. Aphids of the World's Plants: An Online Identification and Information Guide. 2021. Available online: http: / / www.aphidsonworldsplants.info (accessed on 10 January 2021).

10. Kmieć, K.; Kot, I.; Sytykiewicz, H.; Golan, K.; Górska-Drabik, E.; Czerniewicz, P.; Łagowska, B. Aphids' galls-damage or decorative value of host plants? In Proceedings of the 5th International Scientific Horticulture Conference, Nitra, Slovakia, 21-23 September 2016; Šlosár, M., Ed.; Slovak University of Agriculture: Nitra, Slovakia, 2016; pp. 44-48.

11. Gailite, A.; Andersone, U.; Ievinsh, G. Arthropod-induced neoplastic formations on trees change photosynthetic pigment levels and oxidative enzyme activities. J. Plant Interact. 2005, 1, 61-67. [CrossRef]

12. Kmieć, K.; Rubinowska, K.; Michałek, W.; Sytykiewicz, H. The effect of galling aphids feeding on photosynthesis photochemistry of elm trees (Ulmus sp.). Photosynthetica 2018, 56, 989-997. [CrossRef]

13. Oliveira, D.C.; Isaias, R.M.S. Cytological and histochemical gradients induced by a sucking insect in galls of Aspidosperma australe Arg. Muell (Apocynaceae). Plant Sci. 2010, 178, 350-358. [CrossRef]

14. Oliveira, D.C.; Isaias, R.M.S.; Moreira, A.S.F.P.; Magalhães, T.A.; Lemos-Filho, J.P. Is the oxidative stress caused by Aspidosperma spp. galls capable of altering leaf photosynthesis? Plant Sci. 2011, 180, 489-495. [CrossRef]

15. Kmieć, K.; Rubinowska, K.; Golan, K. Tetraneura ulmi (Hemiptera: Eriosomatinae) induces oxidative stress and alters antioxidant enzyme activities in elm leaves. Environ. Entomol. 2018, 47, 840-847. [CrossRef]

16. Kot, I.; Rubinowska, K. Physiological response of pedunculated oak trees to gall-inducing Cynipidae. Environ. Entomol. 2018, 47, 669-675. [CrossRef]

17. Kot, I.; Kmieć, K. Poplar tree response to feeding by the petiole gall aphid Pemphigus spyrothecae Pass. Insects 2020, 11, 282. [CrossRef] [PubMed]

18. Morkunas, I.; Mai, V.C.; Gabryś, B. Phytohormonal signalling in plant responses to aphid feeding. Acta Physiol. Plant. 2011, 33, 2057-2073. [CrossRef]

19. Durak, R.; Bednarski, W.; Formela-Luboińska, M.; Woźniak, A.; Borowiak-Sobkowiak, B.; Durak, T.; Dembczyński, R.; Morkunas, I. Defense responses of Thuja orientalis to infestation of anholocyclic species aphid Cinara tujafilina. J. Plant Physiol. 2019, 232, 160-170. [CrossRef] [PubMed]

20. Sharma, P.; Jha, A.B.; Dubey, R.S.; Pessarakli, M. Reactive oxygen species, oxidative damage, and antioxidative defense mechanism in plants under stressful conditions. J. Bot. 2012, 26, 217037. Available online: https://www.hindawi.com/journals/jb/2012/217 $037 /$ (accessed on 18 September 2021). [CrossRef]

21. Pandey, S.; Fartyal, D.; Agarwal, A.; Shukla, T.; James, D.; Kaul, T.; Negi, Y.K.; Arora, S.; Reddy, M.K. Abiotic stress tolerance in plants: Myriad roles of ascorbate peroxidase. Front. Plant Sci. 2017, 8, 581. [CrossRef]

22. Yates, A.D.; Michel, A. Mechanisms of aphid adaptation to host plant resistance. Curr. Opin. Insect Sci. 2018, 26, 41-49. [CrossRef] [PubMed]

23. War, A.R.; Paulraj, M.G.; Ahmad, T.; Buhroo, A.A.; Hussain, B.; Ignacimuthu, S.; Sharma, H.C. Mechanisms of plant defense against insect herbivores. Plant Signal. Behav. 2012, 7, 1306-1320. [CrossRef]

24. Caverzan, A.; Casassola, A.; Brammer, S.P. Reactive oxygen species and antioxidant enzymes involved in plant tolerance to stress. In Abiotic and Biotic Stress in Plants-Recent Advances and Future Perspectives; Shanker, A., Ed.; InTech: London, UK, 2016; pp. 463-480. Available online: https://mts.intechopen.com/books/abiotic-and-biotic-stress-in-plants-recentadvances-andfuture-perspectives/reactive-oxygen-species-andantioxidant-enzymes-involved-in-plant-tolerance-to-stress (accessed on 22 September 2021)

25. Mai, V.C.; Tran, N.T.; Nguyen, D.S. The involvement of peroxidases in soybean seedlings' defense against infestation of cowpea aphid. Arthropod-Plant Interact. 2016, 10, 283-292. [CrossRef]

26. Giordanengo, P.; Brunissen, L.; Rusterucci, C.; Vincent, C.; van Bel, A.; Dinant, S.; Girousse, C.; Faucher, M.; Bonnemain, J.L. Compatible plant-aphid interactions: How aphids manipulate plant responses. C. R. Biol. 2010, 333, 516-523. [CrossRef]

27. Hori, K.; Wada, A.; Shibuta, T. Changes in phenoloxidase activities of the galls on leaves of Ulmus davidana formed by Tetraneura fusiformis (Homoptera: Eriosomatidae). Appl. Entomol. Zool. 1997, 32, 365-371. [CrossRef]

28. El-Akkad, S.; Zalat, S. Populus galls induced by Pemphigus aphids in Sinai. Egypt. J. Biol. 2000, 2, 15-19.

29. Inbar, M.; Mayer, R.T.; Doostdar, H. Induced activity of pathogenesis related (PR) proteins in aphid galls. Symbiosis 2003, 34, 293-300. 
30. Samsone, I.; Andersone, U.; Ievinsh, G. Variable effect of arthropod-induced galls on photochemistry of photosynthesis, oxidative enzyme activity and ethylene production in tree leaf tissues. Environ. Exp. Biol. 2012, 10, 15-26.

31. Takei, M.; Yoshida, S.; Kawai, T.; Hasegawa, M.; Suzuki, Y. Adaptive significance of gall formation for gall-inducing aphids on Japanese elm trees. J. Insect. Physiol. 2015, 72, 43-51. [CrossRef]

32. Kmieć, K.; Sempruch, C.; Chrzanowski, G.; Czerniewicz, P. The effect of Tetraneura ulmi L. galling process on the activity of amino acid decarboxylases and the content of biogenic amines in Siberian elm tissues. Bull. Entomol. Res. 2018, 108, 69-76. [CrossRef] [PubMed]

33. Kmieć, K.; Złotek, U.; Jakubczyk, A.; Karaś, M. Biochemical alterations in Ulmus pumila L. leaves induced by galling aphid Tetraneura ulmi L. Acta Sci. Pol.-Hortorum Cultus 2018, 17, 175-183. [CrossRef]

34. Jena, S.; Choudhuri, M.A. Glycolate metabolism of three submerged aqutatic angiosperms during aging. Aquat. Bot. 1981, 12, 345-354. [CrossRef]

35. Heath, R.L.; Packer, L. Effect of light on lipid peroxidation in chloroplasts. Biochem. Biophys. Res. Commun. 1968, 19, 716-720. [CrossRef]

36. Kościelniak, J. Wpływ Następczy Temperatur w Termoperiodyzmie Dobowym na Produktywność Fotosyntetyczną Kukurydzy (Zea mays L.)/Successive Effect of Temperature Daily Thermoperiodism in the Photosynthetic Productivity of Maize (Zea mays L.) Ph.D. Thesis, University of Agriculture, Cracow, Poland, 1993. (In Polish)

37. Chance, B.; Meahly, S.K. Assays of catalase and peroxidases. Methods Enzymol. 1955, 2, 764-775.

38. Wiloch, U.; Mioduszewska, H.; Banaś, A. The influence of alloxydim on the antioxidant enzymatic activity in the roots maize (Zea mays L.). Acta Physiol. Plant. Supl. 1999, 21, 535-541.

39. Małolepsza, A.; Urbanek, H.; Polit, J. Some biochemical of strawberry plants to infection with Botrytis cinerea and salicylic acid treatment. Acta Agrobot. 1994, 47, 73-81. [CrossRef]

40. Nakano, Y.; Asada, K. Hydrogen peroxide is scavenged by ascorbate specific peroxidase in spinach chloroplasts. Plant Cell Physiol. 1981, 22, 867-880

41. Statistica StatSoft Inc. Data Analysis Software System. Version 13.1. 2016. Available online: www.ststsoft.com (accessed on 12 July 2021)

42. Mai, V.C.; Bednarski, W.; Borowiak-Sobkowiak, B.; Wilkaniec, B.; Samardakiewicz, S.; Morkunas, I. Oxidative stress in pea seedling leaves in response to Acyrthosiphon pisum infestation. Phytochemistry 2013, 93, 49-62. [CrossRef]

43. Sytykiewicz, H.; Łukasik, I.; Goławska, S.; Chrzanowski, G. Aphid-triggered changes in oxidative damage markers of nucleic acids, proteins, and lipids in maize (Zea mays L.) seedlings. Int. J. Mol. Sci. 2019, 20, 3742. [CrossRef] [PubMed]

44. Isaias, R.M.S.; Oliveira, D.C. Gall phenotypes-Product of plant cells defensive responses to the inducers attack. In Plant Defense: Biological Control; Mérillon, J.M., Ramawat, K.G., Eds.; Springer: Dordrecht, The Netherlands, 2012 ; Volume 12, pp. $273-290$.

45. Isaias, R.M.S.; Oliveira, D.C.; Moreira, A.S.F.P.; Soares, G.L.G.; Carneiro, R.G.S. The imbalance of redox homeostasis in arthropodinduced plant galls: Mechanisms of stress generation and dissipation. Biochim. Biophys. Acta 2015, 1850, 1509-1517. [CrossRef] [PubMed]

46. Łukasik, I.; Goławska, S. Effect of host plant on levels of reactive oxygen species and antioxidants in the cereal aphids Sitobion avenae and Rhopalosiphum padi. Biochem. Syst. Ecol. 2013, 51, 232-239. [CrossRef]

47. Khattab, H.; Khattab, I. Responses of Eucalypt trees to the insect feeding (gall-forming psyllid). Int. J. Agric. Biol. 2005, 7, 979-984.

48. Chmielowska-Bak, J.; Izbianska, K.; Deckert, J. Products of lipid, protein and RNA oxidation as signals and regulators of gene expression in plants. Front. Plant Sci. 2015, 6, 405. [CrossRef] [PubMed]

49. Bhattacharjee, S. Membrane lipid peroxidation and its conflict of interest: The two faces of oxidative stress. Curr. Sci. 2014, 107, 1811-1823.

50. Demidchik, V.; Straltsova, D.; Medvedev, S.S.; Pozhvanov, G.A.; Sokolik, A.; Yurin, V. Stress-induced electrolyte leakage: The role of $\mathrm{K}^{+-}$permeable channels and involvement in programmed cell death and metabolic adjustment. J. Exp. Bot. 2004, 65, 1259-1270. [CrossRef] [PubMed]

51. Sofo, A.; Scopa, A.; Nuzzaci, M.; Vitti, A. Ascorbate peroxidase and catalase activities and their genetic regulation in plants subjected to drought and salinity stresses. Int. J. Mol. Sci. 2015, 16, 13561-13578. [CrossRef]

52. Łukasik, I.; Goławska, S.; Wójcicka, A. Effect of cereal aphid infestation on ascorbate content and ascorbate peroxidase activity in triticale. Pol. J. Environ. Stud. 2012, 21, 1937-1941.

53. Caverzan, A.; Passaia, G.; Rosa, S.B.; Ribeiro, C.W.; Lazzarotto, F.; Margis-Pinheiro, M. Plant responses to stresses: Role of ascorbate peroxidase in the antioxidant protection. Genet. Mol. Biol. 2012, 35, 1011-1019. [CrossRef] [PubMed]

54. Golan, K.; Kot, I.; Górska-Drabik, E.; Jurado, I.; Kmieć, K.; Łagowska, B. Physiological response of basil plants to Twospotted spider mite (Acari: Tetranychidae) infestation. J. Econ. Entomol. 2019, 112, 948-956. [CrossRef]

55. Corpas, F.J.; Barroso, J.B.; Palma, J.M.; Rodriguez-Ruiz, M. Plant peroxisomes: A nitro-oxidative cocktail. Redox Biol. 2017, 11, 535-542. [CrossRef]

56. Foyer, C.H.; Shigeoka, S. Understanding oxidative stress and antioxidant functions to enhance photosynthesis. Plant Physiol. 2011, 155, 93-100. [CrossRef] 
57. Shim, I.S.; Momose, Y.; Yamamoto, A.Y.; Kim, D.W.; Usui, K. Inhibition of catalase activity by oxidative stress and its relationship to salicylic acid accumulation in plants. Plant Growth Regul. 2003, 39, 285-292. [CrossRef]

58. Apel, K.; Hirt, H. Reactive oxygen species: Metabolism, oxidative stress, and signal transduction. Annu. Rev. Plant Biol. 2004, 55, 373-399. [CrossRef] [PubMed] 